\title{
WISATA ALAM KABUPATEN LIMA PULUH KOTA MEMBUKA PELUANG USAHA BAGI MASYARAKAT
}

\author{
Yeni Erita \\ Program Studi Pendidikan Geografi STKIP PGRI Sumatera Barat \\ yenierita261@gmail.com
}

\begin{abstract}
The purpose of this research is to determine the nature contained and dispersed in the District Fifty Cities that can open up business opportunities for the local population. Natural state is owned by the City District Fifty is a natural resource that has been built and developed into a tourist attraction presented by the landscape to the audience, so it has a charm that is intended as a tourist. The method used in this research is descriptive qualitative, which intends to describe and narrate stretch of natural attractions located in the district of Lima City. The results that this is a reference nature to be visited by the visitors and the benefit and satisfaction of natural attractions Fifty Cities and counties get a good service to menikmat so that the service stepping indulgence for the nature lovers. With the ministry's stepping opens opportunities for people who are around him, both in terms of sauvenir and cafes that serve regional specialties Fifty Cities districts themselves.
\end{abstract}

Keywords: Object, Tour, Landscape.

Abstrak

Tujuan dalam penelitian ini adalah untuk mengetahui wisata alam yang terdapat dan tersebar di Kabupaten Lima Puluh Kota yang dapat membuka peluang usaha bagi masyarakat sekitar. Keadaan alam yang dimiliki oleh Kabupaten Lima Puluh Kota merupakan sumber daya alam yang telah dibangun dan dikembangkan menjadi objek wisata yang disuguhkan oleh bentangan alam kepada penikmatnya, sehingga memiliki daya tarik yang ditujukan sebagai tempat wisata. Metode yang dipergunakan dalam penelitian ini adalah deskriptif kualitatif, yang bermaksud menggambarkan dan menarasikan bentangan objek wisata alam yang terdapat di kabupaten Lima Kota. Hasil yang didapat bahwa wisata alam ini merupakan rujukan untuk dapat dikunjungi oleh para pengunjung dan mendapatkan manfaat serta kepuasan dari objek wisata alam kabupaten Lima Puluh Kota serta mendapatkan pelayanan yang baik kepada menikmat sehingga pelayanan sapta pesona yang memanjakan para penikmat wisata alam tersebut. Dengan adanya pelayanan sapta pesona ini membuka peluang usaha bagi masyarakat yang berada di sekelilingnya, baik dari segi sauvenir maupun kafe-kafe yang menyuguhkan makanan khas daerah kabupaten Lima Puluh Kota sendiri.

\section{PENDAHULUAN}

Pada negara maju, industri pariwisata sudah bukan isu yang baru lagi, bahkan banyak orang melakukan perjalanan wisata sebagai kebutuhan hidup setiap manusia yang semata-mata untuk mencari relaksasi, rasa ingin tahu, mengunjungi sahabat/keluarga, pengalaman dan hiburan untuk melepaskan segala kelelahan dan rasa bosan sebagai dampak dari segala kegiatan rutinitas sehari-hari. Seiring dengan perkembangan sektor kepariwisataan secara global serta peningkatan arus kunjungan wisatawan internasional, maka secara tidak langsung telah berdampak kepada kebutuhan penyediaan segala komponen atau produk-produk pariwisata, terutama pada produk objek wisata alam. 
Perkembangan industri pariwisata tersebut tidak hanya berdampak pada peningkatan penerimaan devisa negara, namun pada kenyataannya pariwisata dapat memperluas kesempatan berusaha dan memberikan lapangan pekerjaan baru bagi masyarakat dalam rangka mengurangi permasalahan pengangguran. Tiap tahun angka kunjungan wisatawan mancanegara di Sumatera Barat terus mengalami peningkatan, sehingga telah menyebabkan terjadinya berbagai perubahan global sebagai akibat dari perkembangan dunia pariwisata, baik perubahan pola, bentuk dan sifat kegiatan, dorongan orang untuk melakukan perjalanan wisata, cara berpikir, maupun sifat perkembangan itu sendiri.

Untuk mendukung industri pariwisata, khususnya dalam rangka penyediaan seluruh komponen industri pariwisata pada suatu daerah tujuan wisata, terutama wisata alam maka perlu dilakukan suatu perencanaan yang baik dan terpadu dengan melibatkan seluruh unsur terkait atau stakeholder, seperti pemerintah, tenaga ahli pariwisata, masyarakat setempat (yang terlibat dalam usaha wisata) dan para pemangku kepentingan lainnya. Perencanaan penyediaan produk-produk wisata tersebut tidak hanya akan berdampak positif dalam rangka menarik minat wisatawan untuk berkunjung ke daerah tujuan wisata (DTW), namun juga untuk memotivasi para pelaku industri pariwisata untuk lebih innovatif, kreatif dan menciptakan nilai tambah (value added) terhadap berbagai produk atau pelayanan (services) yang akan diberikan kepada para wisatawan yang akan berkunjung.

Kabupaten Lima Puluh Kota merupakan daerah tujuan wisata (DTW) alam yang tidak ada duanya di dunia ini, yang merupakan kebanggaan masyarakat kabupaten Lima Puluh Kota seperti dengan adanya wisata alam Lembah Harau, Sarasah Tanggo, Wisata Rast area Gunung Sanggul, Sarasah Bunta, Kapalo Banda, dan Kelok Sembilan. Semua objek wisata alam ini menjanjikan bagi masyarakat sekitar untuk bisa membuka usaha, guna menyuguhkan sabta pesona yang diinginkan oleh semua penikmat wisata.

Bila dilihat dari unsur-unsur geografis suatu daerah memiliki potensi dan karakteristik yang berbeda-beda. Bentang alam pegunungan yang beriklim sejuk, pantai landai yang berpasir putih, hutan dengan beraneka ragam tumbuhan yang langka, danau dengan air yang bersih, merupakan potensi suatu daerah yang dapat 
dikembangkan untuk usaha industri pariwisata. Unsur geografis yang lain seperti lokasi/letak, kondisi morfologi, penduduk, berpengaruh terhadap kemungkinan pengembangan potensi obyek wisata, terutama wisata alam.

Dengan adanya Undang-undang No. 32 tahun 2003 tentang Otonomi Daerah, setiap daerah di Indonesia berupaya memperoleh Pendapatan Asli Daerah Setempat (PADS). Salah satu upaya untuk memperoleh pemasukan pendapatan tersebut dengan menggalakkan kegiatan pariwisata yang ada di daerah masingmasing.

Daya Tarik Wisata Alam adalah sumber daya alam yang berpotensi serta memiliki daya tarik bagi pengunjung baik dalam keadaan alami maupun setelah ada usaha budi daya. Pengembangan pariwisata sangat ditentukan oleh seberapa besar potensi supply dan demand. Potensi supply memberikan gambaran seberapa besar daya tarik obyek wisata yang dimiliki oleh suatu Daerah Tujuan Wisata (DTW), hal inilah yang menjadi suatu peluang usaha bagi pemerintah maupun bagi masyarakat setempat. Peluang yang bisa dimanfaatkan oleh masyarakat setempat adalah dengan membuka yang ditawarkan oleh sapta pesona yaitunya kenangan (salah satunya adalah dengan sauvenir-sauvenir yang disuguhkan untuk para mengunjung objek wisata tersebut). Sedangkan potensi demand memberikan gambaran seberapa besar potensi wisatawan yang datang dari Daerah Asal Wisatawan (DAW), hal ini merupakan peluang bagi pemerintah dengan adanya retribusi masuk ke objek wisata.

\section{METODOLOGI}

Metode yang dipergunakan dalam penelitian objek wisata alam ini adalah deskriptif kualitatif, yaitu memberikan gambaran kepada masyarakat/pengunjung akan keindahan wisata alam yang ada di Kabupaten Lima Puluh Kota. Penelitian deskriptif dapat diartikan sebagai prosedur pemecahan masalah yang diselidiki dengan menggambarkan dan melukiskan keadaan objek penelitian pada saat sekarang berdasarkan fakta yang tampak atau sebagaimana adanya, metode deskriptif dengan memusatkan perhatian pada penemuan fakta-fakta sebagaimana keadaan sebenarnya. Fenomena yang diperoleh kemudian dianalisis, sehingga bisa disuguhkan kepada para penikmat objek wisata, Nasution (2000). 
Pengumpulan data dilakukan dengan teknik wawancara mendalam dan pengamatan. Teknik wawancara ini dilakukan melalui serangkaian pertanyaan yang telah dipersiapkan terlebih dahulu, kemudian dengan membawa pedoman wawancara tersebut kepada masyarakat yang memanfaatkan objek wisata alam sebagai peluang usaha dan masyarakat pengunjung sebagai penikmat dari suguhan objek wisata alam yang ada di kabupaten Lima Puluh Kota. Selain itu juga dipergunakan cara pengumpulan data sekunder.

Definisi operasional yang dimaksudkan dalam penelitian ini adalah objek wisata alam yaitu, bentangan yang bisa dinikmati oleh pengunjung yang dapat memanjakan mata, menyenangkan hati, bisa menghirup udara segar dari penyunjung, yang berada di objek wisata Lembah Harau, Sarasah Tanggo, Wisata Rast area Gunung Sanggul, Sarasah Bunta, Kapalo Banda, dan Kelok Sembilan. Analisis yang dilaksanakan dalam penelitian ini lebih bersifat analisis deskriptif.

\section{PEMBAHASAN}

Untuk mengetahui peluang usaha yang dimanfaatkan oleh masyarakat dengan adanya objek wisata alam maka diperlukan informasi tentang:

\section{Daya tarik wisata alam}

Daya Tarik Wisata Alam adalah sumber daya alam yang berpotensi serta memiliki daya tarik bagi pengunjung baik dalam keadaan alami maupun setelah ada usaha budi daya. Potensi wisata alam dapat dibagi menjadi 4 kawasan yaitu

1. Flora fauna.

2. Keunikan dan kekhasan ekosistem, misalnya eksistem pantai dan ekosistem hutan bakau.

3. Gejala alam, misalnya kawah, sumber air panas, air terjun dan danau.

4. Budidaya sumber daya alam, misalnya sawah, perkebunan, peternakan, usaha perikanan.

Beberapa hal yang perlu diperhatikan dalam me-manage pada bidang kepariwisataan, objek dan daya tarik wisata serta pelayanan, hal ini yang perlu diperhatikan dalam perencanaan, pengelolaan dan pemasaran. 


\section{Pengelolaan Objek dan Daya Tarik Wisata}

Perencanaan sebelum pengelolaan suatu objek dan daya tarik wisata guna berhasil sesuai tujuan, A.Yoeti (1990: 285), terdapat tiga faktor yang perlu diperhatikan, yaitu;

a. Objek atraksi wisata, hal menarik yang disediakan dan untuk diselenggarakan.

b. Fasilitas aksesibilitas, kemudahan akses menuju tempat wisata.

c. Value of The Object, bernilai tingginya tempat wisata yang dikunjungi dan dilihat.

Dalam pengelolaan wisata dan daya tarik wisata dapat yang perlu diperhatikan ialah;

a. Pembangunan pada sarana dan prasarana beserta fasilitas pelayanan, dalam pembangunan sarana dan prasarana perlu adanya pengesahan serta peraturan keputusan dari pemerintahan atau yang berwewenang sesuai daerahnya. Begitu pula dengan pembentukan dan pengaturan pada fasilitas pelayanan.

b. Pengelolaan pada sarana dan prasarana, setelah terbentuknya peraturan maka pengelolaan dapat dijalankan dengan petunjuk dan ketetapan yang telah diputuskan secara tertulis dan terjadwal.

c. Penyediaan sarana dan fasilitas, penyediaan ini dapat diatur langsung dari pemerintah, atau dapat juga bantuan partisipasi dari masyarakat sekitar dengan batasan-batasan aturan yang ada.

d. Penyelenggaraan kearifan yang ada pada tempat wisata, hal ini yang biasanya menjadi program daya tarik pada waktu (event) tertentu, sehingga tempat wisata lebih variatif, seperti; pementasan nilai budaya yang ada di tempat wisata tersebut, sebagaimana menjadi nilai tambah untuk daya tarik wisatawan. Dalam pementasan industri wisata biasanya mengundang seseorang penting atau yang sedang digemari masyarakat.

Dalam daya tarik wisata perlu juga dilakukan beberapa hal, diantaranya:

Pemasaran pariwisata merupakan usaha mengaktualisasikan perjalanan wisata, dimana tujuan akhirnya ialah agar orang membeli produk yang ditawarkan. Soekardjo (2000: 217).

Pemasaran pariwisata mencakup; menemukan apa yang menjadi keinginan konsumen (market reason), mengembangkan pemberian pelayanan yang sesuai kepada wisatawan (product planning) pemberitahuan tentang produk yang 
dibuat (advertising and promotion) dan memberikan intruksi dimana wisatawan dapat memperoleh produk-produk tersebut (chamels of distribution-tour operator and travel agent). Marpaung (2002: 118)

Pemasaran pariwisata dapat dipahami bahwa suatu cara usaha industri wisata membuat wisatawan akan mengunjungi, melihat, dan membayar atau membeli yang disediakan atau yang diproduksi di tempat wisata.

Dalam pemasaran perlu adanya penyesuaian antara produk paiwisata dengan permintaan pasar wisata, hal ini disebut promosi wisata. Setelah tindakan promosi, maka hasil penyesuaian itu diciptakan menjadi suatu yang dapat mempengaruhi permintaan pasar wisata dengan cara menonjolkan keinginan pasar wisata, ini disebut publikasi wisata.

\section{Promosi}

Melakukan penyesuaian produk wisata dengan permintaan pasar wisata dapat dibedakan menjadi dua, secara langsung dan tidak langsung:

a. Promosi secara langsung:

1. Pameran atau Peragaan (display), misalnya peragaan rumah adat, pergaan pakaian tradisional, benda-benda tradisional yang bernilai tinggi.

2. Mengadakan pagelaran mengenai produk wisata, atau menyediakan tempat pagelaran atau acara dari tempat wisata dengan mengundang sesuatu atau seseorang yang dianggap digemari pasar wisata.

3. Pemberian hadiah selama promosi, seperti; diskon tiket masuk produk wisata, sticker produk, free atau diskon dari produk lain yang sekiranya diperlukan.

b. Promosi secara tidak langsung:

1. Pemampangan info mengenai produk wisata di tempat yang sesuai pasar; seperti poster, spanduk, atau baliho.

2. Penyebaran informasi wisata, seperti brosur, booklet, pamplet, dsb

3. Mengunjungi perusahaan penyalur yang dapat membantu menginformasikan produk wisata, dengan mempersentasikan produk wisata kepada perusahaan penyalur. 


\section{Publikasi}

Dalam mempublikasikan produk wisata, hal yang harus diperhatikan ialah bagaimana tindak promosi dapat sampai dan diterima langsung dengan baik kepada pasar. Cara mempublikasikan dapat dibedakan sesuai medianya:

a. Media Cetak, seperti penyebaran dari tangan ke tangan, dan pemasangan atau penempelan; brosur, pamlet, booklet, ataupun poster dan baliho.

b. Media Elektronik, melakukan info pomosi melalui radio, televisi, ataupun melalui akses internet; web site atau berbagai jejaring sosial.

Dari pembahasan mengenai me-manage kepariwisataan ini merupakan penjabaran dari teori-teori yang ada sehingga dapat dilakukan pe-manage-an kepariwisataa dengan dimulai dari perencanaan dan pengelolaan serta pemasaran dengan promosi dan publikasi.

\section{Permintaan Pasar Wisata}

Dalam pengelolaan sampai pemasaran pariwisata, permintaan pasar juga merupakan hal penting yang perlu diperhatikan sebagaimana permintaan pasar sebagai faktor pengaruh tujuan dari tindak pengelolaan dan pemasaran pariwisata. Permintaan pasar dapat dibedakan menjadi beberapa kelas dan beberapa bidang, seperti membedakan kelas dapat dibedakan sesuai geografi atau tempat;

1. Permintaan pasar di desa (lokal), dari segi sifat dapat dibagi lagi menjadi dua dan tegantung dengan jenis wisata, pada wisata alam yang mana kebanyakan justru alam itu milik mereka, maka akan bersifat hal yang biasa dengan mengunjungi wisata alam dan budaya, berbeda dangan wisata atraksi atau tempat rekreasi, ini akan bersifat keingintahuan dan hiburan.

2. Permintaan pasar di kota, kebanyakan permintaan pasar di kota adalah bersifat hiburan dan ketenangan, karena faktor aktivitas kesibukan di kota.

3. Permintaan pasar di luar negara, permintaan untuk yang ini lebih variatif dan perlu banyak hal yang dilakukan guna permintaan pasar di luar negara lebih banyak permintaan, seperti keamanan, pelayanan dan tujuan wisata yang berguna serta bernilai lebih untuk mereka karena faktor perbedaan budaya dan aturan. 
Dari segi permintaan pasar wisata, ada beberapa aspek penting yang perlu diperhatikan guna bertujuan memuaskan permintaan pasar dalam berpariwisata:

1. Keamanan, maksud keamanan disini secara umum ialah tidak adanya ancaman bahaya apapun jika wisatawan berwisata ke tempat wisata, baik selama perjalanan maupun saat sampai di tempat wisata.

2. Transportasi dan pelayanannya, yang dimaksud ialah bagaimana wisatawan dengan mudah dan nyaman melakukan perjalanan dan sampai di tempat sesuai permintaan wisatawan, serta biaya yang sesuai dengan pelayanannya.

3. Pelayanan tempat wisata, sudah pasti pelayanan merupakan faktor terpenting kedua selain produk wisata itu sendiri, pelayanan yang baik dan dibutuhkan yang dapat memuaskan permintaan pasar.

4. Penyediaan produk wisata, dalam penyediaan produk yang membuat wisatawan merasa senang dengan mengunjungi, melihat atau mendapatkan sesuatu dari tempat atau produk yang disediakan dalam berwisata.

\section{Atraksi Wisata}

Suatu daerah tujuan wisata, akan disebut daerah objek wisata apabila memiliki atraksi-atraksi yang memikat sebagai tujuan kunjungan wisata. Atraksi wisata yang baik akan dapat mendatangkan wisatawan sebanyak-banyaknya, menahan mereka untuk dapat tinggal lebih lama dan memberi kepuasan kepada wisatawan yang berkunjung.

Menurut Soekadijo (1996: 61) syarat suatu atraksi wisata yang baik diantaranya adalah penyajian (presentasinya) harus tepat. Untuk mencapai presentasi yang baik harus mempertimbangkan perspektif ruang, perspektif waktu, dan perspektif sosial budaya.

Strategi-strategi yang dapat dimunculkan untuk dapat meningkatkan mutu atraksi wisata di objek wisata Bendungan adalah:

a. Memanfaatkan keunikan budaya Minangkabau untuk menarik minat wisatawan untuk dapat berkunjung

b. Menyediakan sanggar untuk masyarakat supaya dapat mendalami kesenian dan budaya Minangkabau, sehingga dapat disajikan sebagai atraksi wisata budaya yang unik dan menarik, seperti tari-tarian, upacara adat, rabab dan pencak silat. 
c. Diadakannya kegiatan wisata menikmati pemandangan alam (sight seeing) dan menyediakan tempat-tempat khusus untuk dapat menikmati keindahan alam yang menyajikan atraksi wisata berupa pemandangan danau, perbukitan yang hijau yang jauh dari kebisingan.

d. Menarik perhatian wisatawan yang sudah mengunjungi objek-objek wisata yang berada di Kabupaten Lima Puluh Kota untuk dapat mengunjungi objek wisata.

Objek wisata alam Kabupaten Lima Puluh Kota yang disuguhkan dengan menyajikan bentangan alam atraksi yang unik dan menarik, diantaranya objek wisata Sarasah Tanggo, objek wisata Lembah Harau, objek wisata Kelok Sembilan, objek wisata Rast area Gunung Sanggul, objek wisata Sarasah Bonta, dan objek wisata Kapalo Banda.

Berikut cuplikan gambar bentangan objek wisata alam tersebut.

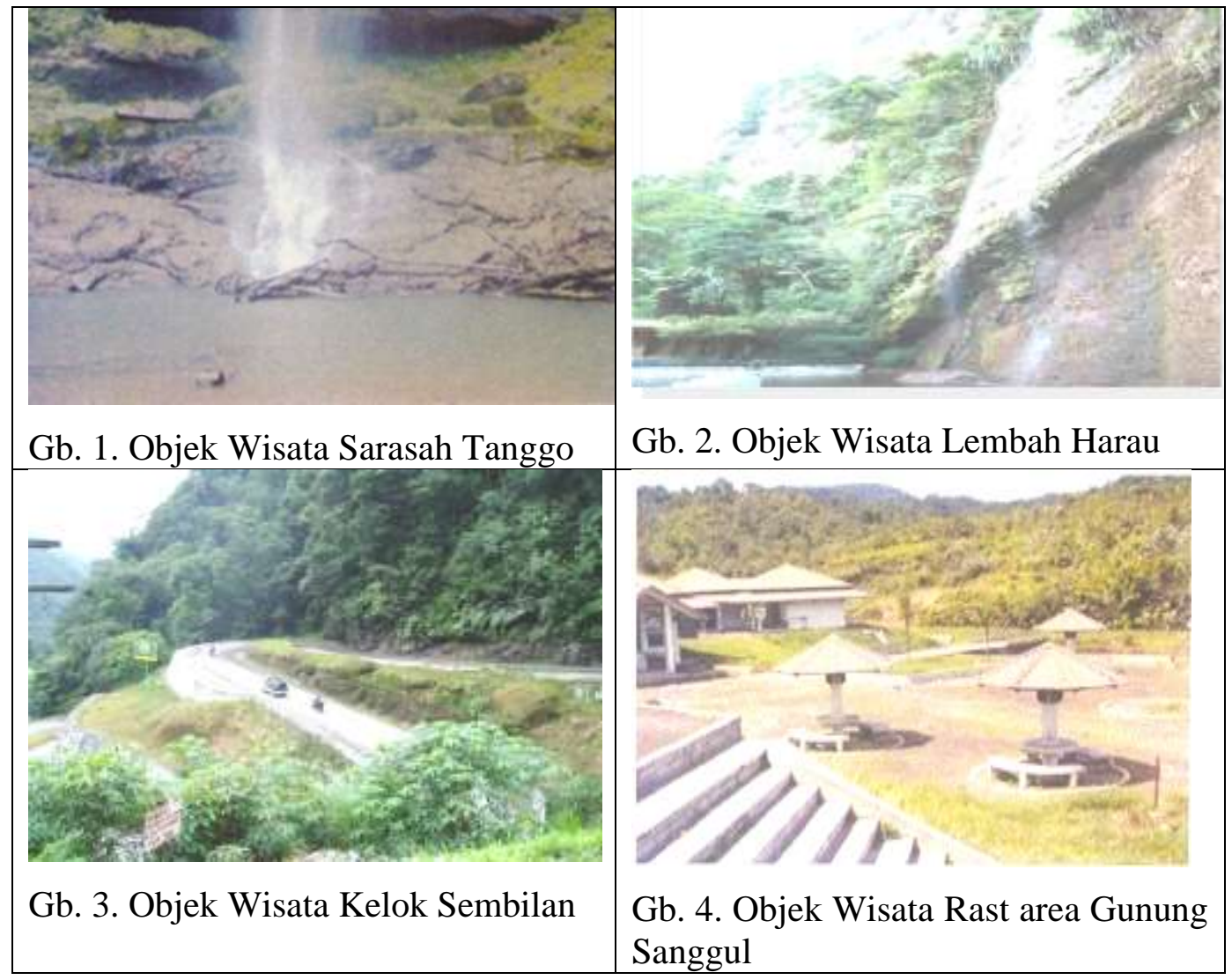




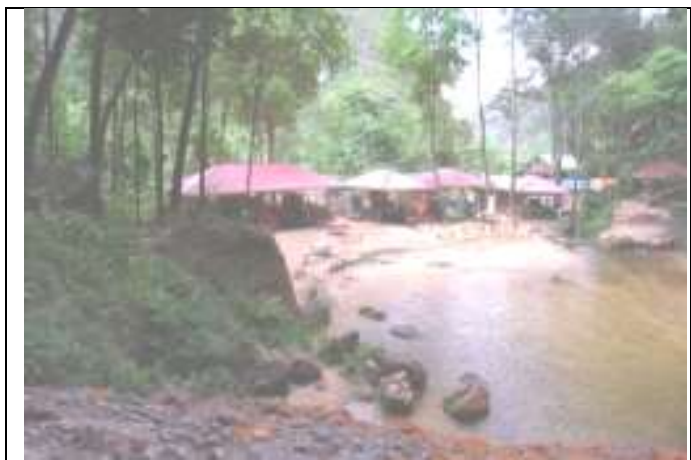

Gb. 5. Objek Wisata Sarasah Bunta

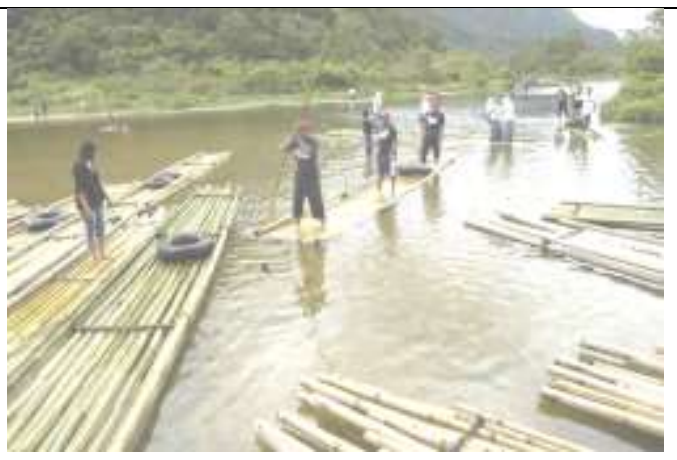

Gb. 6. Objek Wisata Kapalo Banda

Suatu daerah tujuan wisata tidak akan berarti banyak bila aksesibilitas ke obyek wisata tersebut sulit dijangkau, baik lewat darat, laut, maupun udara. Agar pariwisata dapat berkembang dengan baik, maka suatu destinasi haruslah assessibel (bisa didatangi). Oleh karena itu, aksesibilitas menuju dan di sekitar objek/lokasi wisata perlu diperhatikan.

Aksesibilitas yang dimaksud disini ialah jalan dan sarana transportasi. Strategi-strategi yang dapat dimunculkan pada sektor aksesibilitas ini adalah:

1) Memperbaiki prasarana jalan yang rusak, dan segera melakukan pembangunan jalan yang belum diaspal

2) Memasang penunjuk jalan dengan jelas, supaya wisatawan dapat dengan mudah mencapai Kecamatan Harau Kabupaten Lima Puluh Kota.

3) Membuat gerbang masuk (gate way) sebagai penanda memasuki objek misalnya objek wisata Harau yang ada di Kecamatan Harau Kabupaten Lima Puluh Kota dan objek wisata lainnya yang ada di Kabupaten Lima Puluh Kota tersebut.

4) Menyediakan sarana angkutan yang khusus menuju objek wisata alam yang disajikan oleh Kabupaten Lima Puluh Kota, seperti ke enam objek di atas.

Sesuai dengan pendapat James J. Spillane dalam Susanto (2004) mengatakan bahwa pariwisata adalah kegiatan melakukan perjalanan dengan tujuan 
mendapatkan kenikmatan, mencari kepuasan, mengetahui sesuatu, memperbaiki kesehatan, menikmati olahraga atau istirahat, menunaikan tugas, dan berziarah.

Objek wisata yang dapat bernilai tinggi yang dapat dinikmati oleh wisatawan salah satunya adalah tempat wisata yang dapat dikunjungi dan dapat dilihat serta dinikmati oleh wisatawan. Fasilitas yang tersedia di objek wisata alam ini berupa panorama alam yang memanjakan setiap wisatawan, dan penginapan yang mendukung wisatawan dapat beristirahat sambil menikmati keindahan pemandangan alam.

\section{KESIMPULAN}

Sektor pariwisata sangat berperan penting untuk mengait para wisatawan untuk berkunjung kembali ke suatu objek wisata yang sudah pernah dikunjungi. Disamping menyediakan pelayanan dengan sapta pesona yang terkait dengan objek wisata alam yang dinikmati oleh penyunjung. Dengan pelayanan yang bagus dan memuaskan kepada para pengunjung merupakan peluang usaha baik bagi pemerintah sendiri maupun bagi masyarakat sekitar. Rangkaian perjalanan yang hanya dapat dinikmati, apabila seluruh rangkaian perjalanan tersebut dapat memberikan pengalaman yang baik bagi orang yang melakukan perjalanan tersebut.

Bentangan alam yang disuguhkan Kabupaten Lima Puluh Kota merupakan sesuatu yang mempunyai daya tarik, keunikan dan nilai yang tinggi yang tidak dimiliki oleh objek wisata alam daerah lainnya, hal ini yang menjadikan tujuan wisatawan datang lagi ke lokasi wisata alam Lima Puluh Kota ini.

\section{DAFTAR PUSTAKA}

Darma Putra I Nyoman dan Pitana, I Gede. 2010. Pariwisata Pro-Rakyat. Jakarta: Kementerian Kebudayaan dan Pariwista.

Putra, Wyasa. 2010. Fungsi Hukum Dalam Pengaturan Pariwisata Sebagai Bentuk Perdagangan Jasa. Denpasar: Universitas Udayana.

Irianto, Agus. 2002. Pengembangan Pariwisata Berwawasan Lingkungan Padang Kota Tua. Padang. Lembaga Penelitian Universitas Negeri Padang bekerjasama dengan Dinas Pariwisata, Seni dan Budaya Sumatera Barat. 
Kuswiran, Hendri. 2004. Pengembangan Sektor Industri Pariwisata dan Perluasan Kesempatan Kerja Kota Bengkulu. Padang: Tesis, Program Pascasarjana Universitas Negeri Padang.

Mill, Cristie Robert. 2000. Tourism The International Business. Jakarta: Raja Grafindo Persada.

Nasution. 2000. Metode Penelitian Deskriptif. Jakarta: Remaja Karya.

Soekadijo, R.G. 1996. Anatomi Pariwaisata. Jakarta: Gramedia Pustaka Utama.

Undang-undang Otonomi Daerah No. 32 tahun 2003.

Undang-undang Pariwisata No. 10 tahun 2009.

Yoeti, A. Oka 1996. Pengantar Ilmu Pariwisata. Bandung: Angkasa. 